\title{
List of Plates and Figures
}

Plate $1 a \& b \quad$ Lovibond Tintometer

Plate 2 Munsell Color Chart, Munsell Book of Color

Plate 3 Del Monte Advertisement

Plate 4 Jell-O Advertisement

Plates Fruits of the Tropics

Plate 6 Crate Label

Plate 7 Seald Sweet Cook Book

Plate 8 DuPont Advertisement

Figure $3.1 \quad$ H. Kohnstamm \& Co. Advertisement 50

Figure 4.1 "Some Dainty Fruit Desserts for the Summer Table" 74

Figure 5.1 Grocery Store Window Display $\quad$ I03

Figure 5.2 Auction Warehouse at the Pennsylvania Railroad Terminal in New York City $\quad$ I04

Figure 5.3 A Banana Ripening Room in Springfield, Missouri

Figure 6.1 Per Capita Consumption of Margarine and Butter in the United States I29

Figure 6.2 John F. Jelke Company Leaflet I36

Figure 6.3 The Amount of Colored and Uncolored Margarine Produced in the United States $\quad$ I37

Figure 7.1 Grocery Store Floor Plans I6I

Figure 7.2 The Number of Grocery Stores with Self-Service Meat Departments I8I

Figure 8.1 The Amount of Dyes Certified in the United States 
